\title{
Performance of Sugarcane under Different Establishment Techniques and Planting Geometries
}

\author{
Maruthi $^{1}$, D. Krishnamurthy ${ }^{2 *}$, Y.M. Ramesh ${ }^{3}$, \\ B.M. Chittapur ${ }^{1}$ and Ashokkumar Gaddi ${ }^{4}$ \\ ${ }^{1}$ Department of Agronomy, College of Agriculture, Raichur-584104, India \\ ${ }^{2}$ AICRP on Sorghum, Agricultural Research Station, Hagari, India \\ ${ }^{3}$ Agricultural Research Station, Dhadesugur, India \\ ${ }^{4}$ Agricultural Research Station, Siruguppa, Karnataka, India
}

*Corresponding author

\section{A B S T R A C T}

\section{Keywords}

Sugarcane, Setts, Planting techniques and geometries

Article Info

Accepted:

04 October 2019

Available Online:

10 November 2019
A field experiment was conducted on vertisols at Agricultural Research Station, Dhadesugur, University of Agricultural Sciences, Raichur coming under northern Karnataka during 2016-17 to study the Performance of sugarcane under different establishment techniques and planting geometries. Ten treatments were evaluated in different planting techniques and planting geometries in randomized block design with three replications. Among different treatments, two eye budded setts with dual row planting $\left(\mathrm{T}_{6}\right)$ was recorded significantly highest millable cane yield $\left(133 \mathrm{t} \mathrm{ha}^{-1}\right)$, millable canes $\left(11.5 \mathrm{~m}^{-1}\right)$, single cane weight $(1.4 \mathrm{~kg})$, cane length $(258.4 \mathrm{~cm})$, LAI $(2.7)$, total dry matter production (414.6 $\left.\mathrm{g} \mathrm{plant}^{-1}\right)$ and sugar yield $\left(15.2 \mathrm{t} \mathrm{ha}^{-1}\right)$ and which was on par with Two eye budded setts with paired row planting $\left(\mathrm{T}_{5}\right)$ and Two eye budded setts with wide row planting $\left(\mathrm{T}_{4}\right)$. The lowest millable cane yield $\left(102.7 \mathrm{t} \mathrm{ha}^{-1}\right)$, millable canes $\left(7.6 \mathrm{~m}^{-1}\right)$, single cane weight $(1.2 \mathrm{~kg})$, cane length $(210.0 \mathrm{~cm})$, LAI $(2.7)$ and total dry matter production (414.6 $\left.\mathrm{g} \mathrm{plant}^{-1}\right)$ remained non-significant by different planting techniques and planting geometries.

\section{Introduction}

Usually sugarcane is vegetatively propagated. The planting materials used are the stem cuttings known as "sett", each having one or several eyes/buds (Sundara, 2000). Planting techniques and plant geometry play a crucial role in establishment of sugarcane crop which occupies the field for 3-4 years in a plantratoon cropping system. Proper planting 
techniques and the right geometry of planting harness optimum space and light to manifest the resources for the best output. Perhaps this one aspect of non adequate spacing is responsible for lower productivity in sugarcane. Under irrigated conditions, generally 40,000 three budded setts from healthy matured cane are recommended for sugarcane. Saving of seed material by changing the type of seed material (sett size) and seed rate without any deleterious effect on plant stand may help in getting higher cane yield with lower cost of production. Many studies have been conducted on planting geometry but appropriate planting techniques and planting at wider spacing will open new vistas for increasing the productivity of sugarcane. Of the many variables involved in the production of higher cane and sugar yield from sugarcane plant, probably the most important factor is the millable canes per unit area of land at harvest, which can be achieved by manipulating planting geometry/density to greater extent by way of maximizing efficient interception of incident radiant energy. Since, closer spacing hinders the mechanized intercultural operation; adoption of wider spacing is increasing in many parts of India. In recent past wider row spacing is very popular as it helps mechanization of several field operations thereby results in minimization cost of production. However, as spacing increases, number of millable canes can become a limiting factor in sugarcane productivity (Singh et al., 2006).

The primary components of cane yield are cane population and weight of individual cane. Cane population per unit area is directly affected by planting density which changes rapidly with the closer spacing or with the increase in seed rate. Thus, yield level can be increased substantially by manipulating certain cultural practices like spacing, planting material etc. The adaption of optimum spacing, suitable planting pattern/ crop geometry, sett size and sett rate will go a long way in increasing yield and quality of sugarcane. The information on testing of different planting material under various planting techniques is lacking and needs to be worked out. It is, therefore, necessary to standardize the suitable planting techniques with spacing/ plant geometry that may improve the productivity of sugarcane.

\section{Materials and Methods}

A field experiment was conducted at Experimental block, Agricultural Research Station, Dadhesugur which falls under Northern Dry Zone of Karnataka (Zone-III). The experiment comprised of ten treatments viz. $\mathrm{T}_{1}$-Single eye budded setts with wide row planting (120 cm furrow), $\mathrm{T}_{2}$ : Single eye budded setts with paired row planting $(60 \mathrm{~cm}-$ $120 \mathrm{~cm}-60 \mathrm{~cm}$ ), $\mathrm{T}_{3}$ : Single eye budded setts with dual row planting $(30 \mathrm{~cm}-150 \mathrm{~cm}-30$ $\mathrm{cm}), \mathrm{T}_{4}$ : Two eye budded setts with wide row planting $(120 \mathrm{~cm}), \mathrm{T}_{5}$ : Two eye budded setts with paired row planting $(60 \mathrm{~cm}-120 \mathrm{~cm}-60$ $\mathrm{cm}), \mathrm{T}_{6}$ : Two eye budded setts with dual row planting $(30 \mathrm{~cm}-150 \mathrm{~cm}-30 \mathrm{~cm}), \mathrm{T}_{7}$ : Bud chip seedlings with wide row planting (120 $\mathrm{cm}$ furrow), $\mathrm{T}_{8}$ : Bud chip seedlings with paired row planting $(60 \mathrm{~cm}-120 \mathrm{~cm}-60 \mathrm{~cm})$, $\mathrm{T}_{9}$ : Bud chip seedlings with dual row planting (30 cm- $150 \mathrm{~cm}-30 \mathrm{~cm}$ ) and $\mathrm{T}_{10}$ : Three eye budded setts with conventional planting (90 $\mathrm{cm})$. The experiment was laid out with randomized complete block design and three replications. The soil was black clay in texture with slightly alkaline ( $\mathrm{pH}-8.23)$, low in EC $\left(0.20 \mathrm{dSm}^{-1}\right)$ and low in organic carbon content $(0.43 \%)$. The soil was low in available nitrogen (166.8 $\mathrm{kg} \mathrm{ha}^{-1}$ ), high in available phosphorus (55.0 $\left.\mathrm{kg} \mathrm{ha}^{-1}\right)$ and available potassium $\left(300.5 \mathrm{~kg} \mathrm{ha}^{-1}\right)$. All other agronomic practices were kept normal and uniform for all the treatments. The sugarcane variety $2003-\mathrm{V}-46$ was planted on $1^{\text {st }}$ of February, 2016. Fertilizer was applied @ 250 
$\mathrm{kg} \mathrm{N}, 100 \mathrm{~kg} \mathrm{P}_{2} \mathrm{O}_{5}$ and $125 \mathrm{kgK}_{2} \mathrm{O} \mathrm{ha}{ }^{-1}$ in the form of Urea, DAP, and SOP, respectively. The entire dose of $\mathrm{P}, \mathrm{K}$, and $1 / 3 \mathrm{rd}$ of $\mathrm{N}$ were applied as a basal dose at the time of planting, while remaining $\mathrm{N}$ was applied in two splits, $1 / 3$ rd at the start of tillering and 1/3rd before earthing up by side dressing. The crop was harvested manually after its maturity on $29^{\text {th }}$ of February, 2017.Recommended packages of practices were adopted for crop production. The analysis and interpretation of data were done using the Fisher's method of analysis and variance technique as given by Gomez and Gomez (1984). The level of significance used in " $F$ " and " $\mathrm{t}$ " test was at $5 \%$ probability level and wherever " $F$ " test was found significant, the " $t$ " test was performed to estimate critical differences among various treatments.

\section{Procedures and formulas for recording observations}

\section{Plant height (cm)}

The plant height was measured from the base of the plant to the base of the fully opened leaf from five tagged plants and the mean plant height was at harvest and expressed in centimetre.

\section{Millable cane yield ( $\mathrm{tha}^{-1}$ )}

The millable canes in each net plot were cut close to the ground level, the green tops and trash were removed, bundled and weight was recorded and expressed in $\mathrm{kg}$ per net plot and then converted into tonnes per hectare.

\section{Leaf area $\left(\mathrm{dm}^{2}\right.$ plant $\left.^{-1}\right)$}

Leaf area (Length X Breadth) of third, fourth, fifth and sixth leaves from the top were determined in the five selected plant. The leaf area of individual leaves of the plant was calculated by multiplying with a factor, 0.6274
(Bathla and Sharma 1978). The mean leaf area of selected leaves was multiplied by number of leaves per plant to arrive at the leaf area per plant and expressed in deci-meter square.

\section{Leaf area index (LAI)}

Leaf area index at harvest was worked out using the following formula (Sestaket al., 1971).

Leaf area index (LAI)

Total leaf area of plant $\left(\mathrm{dm}^{2}\right)$

Land area occupied by the plant $\left(\mathrm{dm}^{2}\right)$

Dry matter accumulation and its distribution (g plant ${ }^{-1}$ )

The five canes selected from dry matter sampling rows were cut at the base and separated into stem and leaves, chapped separately and kept for air drying in shade. The semi dried material was kept in hot air oven at $65-70{ }^{\circ} \mathrm{C}$ still it reaches constant weight and oven dry weight was recorded. After weighing, the total dry matter production was calculated and was expressed in grams per plant. The mean dry matter of five selected canes from each treatment was recorded at harvest.

\section{Cane length $(\mathrm{cm})$}

Length of the cane was recorded from ground to tip after removing the tops for five sample canes which were selected randomly in each plot at harvest and expressed in meter.

\section{Number of millable canes $\left(\mathrm{m}^{-1}\right)$}

Millable canes refer to the canes that have attained normal height and thickness at their physiological maturity and are ready to harvest for processing. Number of millable canes in each experimental unit was counted 
at harvest and then converted into number of millable canes perm ${ }^{2}$.

\section{Individual cane weight $(\mathrm{kg})$}

The weight of five randomly selected sample millable canes was recorded at harvest and expressed as kg per cane.

\section{Statistical analysis and interpretation of data}

The analysis and interpretation of data recorded on various parameters were done using the Fisher's method of analysis and variance technique as given by Gomez and Gomez (1984). The level of significance used in " $F$ " and " $t$ " test was at 5\% probability level and wherever " $F$ " test was found significant, the " $t$ " test was performed to estimate critical differences among various treatments.

\section{Results and Discussion}

\section{Plant height}

Growing of sugarcane with two eye budded setts with dual row planting $(30 \mathrm{~cm}-150 \mathrm{~cm}$ $30 \mathrm{~cm}$ ) recorded significantly taller plants at harvest $(304.2 \mathrm{~cm})$ and it was on par with the two eye budded setts with paired row $(60 \mathrm{~cm}-$ $120 \mathrm{~cm}-60 \mathrm{~cm})$ planting $(294.9 \mathrm{~cm})$ and two eye budded setts with wide row $(120 \mathrm{~cm})$ planting $(296.3 \mathrm{~cm})$.

Further, planting of sugarcane with single eye budded setts and bud chip seedling with different planting geometries was on par with each other with respect to plant height at various growth stages (Table 1). Whereas, planting of sugarcane with three budded setts (conventional planting) recorded significantly shorter plants at harvest $(249.7 \mathrm{~cm})$. This might be due to good aeration. Shinde et al., (2000), Cheema et al., (2002), Chattha et al., (2007) and Zafar et al., (2010) also noted significant differences in total plant height of sugarcane with various plant geometries.

\section{Leaf area}

Significantly higher leaf area per plant (72.5 $\mathrm{dm}^{2}$ plant $^{-1}$ ) was recorded with two eye budded setts with dual row planting $(30 \mathrm{~cm}$ $150 \mathrm{~cm}-30 \mathrm{~cm}$ ) and it was on par with two eye budded setts with paired row $(60 \mathrm{~cm}-120 \mathrm{~cm}$ $60 \mathrm{~cm})$ planting $\left(68.7 \mathrm{dm}^{2}\right.$ plant $\left.^{-1}\right)$ and two eye budded setts with wide row $(120 \mathrm{~cm})$ planting $\left(67.1 \mathrm{dm}^{2}\right.$ plant $\left.^{-1}\right)$. However, leaf area per plant was on par with planting of sugarcane with single eye budded setts and bud chip seedling with different planting. Whereas, least leaf area per plant $\left(55.1 \mathrm{dm}^{2}\right.$ plant $\left.{ }^{-1}\right)$ was recorded in planting of sugarcane with three budded setts (Table 1). This might be attributed to favourable planting geometry in two eye budded setts planted sugarcane and its better exploitation of available resources for growth compared to other methods of plant geometries.

\section{Leaf area index}

The leaf area index of sugarcane was differed significantly (Table 1). Results exhibited that growing of sugarcane with two eye budded setts with dual row planting $(30 \mathrm{~cm}-150 \mathrm{~cm}$ $30 \mathrm{~cm}$ ) recorded significantly higher leaf area index (2.7) and it was on par with the two eye budded setts with paired row $(60 \mathrm{~cm}-120 \mathrm{~cm}-$ $60 \mathrm{~cm}$ ) planting (2.5) and two eye budded setts with wide row $(120 \mathrm{~cm})$ planting $(2.3)$.

Further, leaf area index of sugarcane was on par with planting of sugarcane bud chip seedling with different planting geometries. Whereas, planting of sugarcane with three budded setts (conventional planting) recorded significantly least leaf area index at harvest (2.0).More leaf area per plant, better leaf expansion and development can be the causal agents for these results. The findings are in 
line with AhmadIftikhar (2002) mentioned that wider row spacing had significant effect on LAI.

\section{Total dry matter production}

Total dry matter production was significantly influenced by the establishment techniques and planting geometries (Table 1). Results revealed that growing of sugarcane with two eye budded setts with dual row planting (30 $\mathrm{cm}-150 \mathrm{~cm}-30 \mathrm{~cm})$ recorded significantly higher total dry matter (414.6 g plant $\left.{ }^{-1}\right)$ and it was on par with the two eye budded setts with paired row $(60 \mathrm{~cm}-120 \mathrm{~cm}-60 \mathrm{~cm})$ planting
(410.1 $\mathrm{g} \mathrm{plant}^{-1}$ ) and two eye budded setts with wide row $(120 \mathrm{~cm})$ planting $(401.9 \mathrm{~g}$ plant $\left.^{-1}\right)$. Further, total dry matter production of sugarcane was on par with planting of sugarcane with single eye budded setts and bud chip seedling with different planting geometries. Whereas, conventional planting $(90 \mathrm{~cm})$ recorded significantly lower total dry matter production at harvest $\left(382.0 \mathrm{~g} \mathrm{plant}^{-1}\right)$. This was attributed to better growth of plant in terms of plant height. Similarly, Shinde et al., (2000) and Rehman et al., (2013) observed higher dry matter accumulation in plant under dual row planting.

Table.1 Plant height, Leaf area, Leaf area index and Total dry matter production of sugarcane as influenced by different establishment techniques and planting geometries

\begin{tabular}{|c|c|c|c|c|}
\hline Treatments & $\begin{array}{l}\text { Plant } \\
\text { height } \\
\text { (cm) }\end{array}$ & $\begin{array}{l}\text { Leaf area } \\
\left(\mathbf{d m}^{2} \text { plant }^{-1}\right)\end{array}$ & $\begin{array}{l}\text { Leaf area } \\
\text { index }\end{array}$ & $\begin{array}{l}\text { Total dry matter } \\
\text { production } \\
\left(\mathrm{g} \text { plant }^{-1}\right)\end{array}$ \\
\hline $\begin{array}{l}\mathrm{T}_{1} \text { : Single eye budded setts with wide row } \\
\text { planting }(120 \mathrm{~cm} \text { furrow })\end{array}$ & 267.6 & 61.4 & 1.7 & 386.3 \\
\hline $\begin{array}{l}T_{2}: \text { Single eye budded setts with paired row } \\
\text { planting }(60 \mathrm{~cm}-120 \mathrm{~cm}-60 \mathrm{~cm})\end{array}$ & 270.9 & 61.9 & 1.7 & 387.5 \\
\hline $\begin{array}{l}T_{3} \text { : Single eye budded setts with dual row } \\
\text { planting }(30 \mathrm{~cm}-150 \mathrm{~cm}-30 \mathrm{~cm})\end{array}$ & 279.4 & 65.1 & 1.8 & 388.2 \\
\hline $\begin{array}{c}\mathrm{T}_{4} \text { : Two eye budded setts with wide row } \\
\text { planting }(120 \mathrm{~cm})\end{array}$ & 296.3 & 67.1 & 2.5 & 401.9 \\
\hline $\begin{array}{l}T_{5}: \text { Two eye budded setts with paired row } \\
\text { planting }(60 \mathrm{~cm}-120 \mathrm{~cm}-60 \mathrm{~cm})\end{array}$ & 294.9 & 68.7 & 2.5 & 410.1 \\
\hline $\begin{array}{c}\mathrm{T}_{6}: \text { Two eye budded setts with dual row } \\
\text { planting }(30 \mathrm{~cm}-150 \mathrm{~cm}-30 \mathrm{~cm})\end{array}$ & 304.2 & 72.5 & 2.7 & 414.6 \\
\hline $\begin{array}{l}\mathrm{T}_{7} \text { : Bud chip seedling with wide row } \\
\text { planting }(120 \mathrm{~cm} \text { furrow })\end{array}$ & 256.5 & 55.8 & 2.1 & 384.5 \\
\hline $\begin{array}{l}\mathrm{T}_{8} \text { : Bud chip seedling with paired row } \\
\text { planting }(60 \mathrm{~cm}-120 \mathrm{~cm}-60 \mathrm{~cm})\end{array}$ & 257.7 & 58.0 & 2.2 & 385.3 \\
\hline $\begin{array}{l}T_{9} \text { : Bud chip seedling with dual row planting } \\
\qquad(30 \mathrm{~cm}-150 \mathrm{~cm}-30 \mathrm{~cm})\end{array}$ & 260.4 & 60.0 & 2.2 & 386.1 \\
\hline $\begin{array}{l}\mathrm{T}_{10}: \text { Three eye budded setts with } \\
\text { conventional planting }(90 \mathrm{~cm})\end{array}$ & 249.7 & 55.1 & 2.0 & 382.0 \\
\hline S.Em. \pm & 7.9 & 1.9 & 0.1 & 3.6 \\
\hline C.D. $(P=0.05)$ & 23.5 & 5.6 & 0.3 & 10.6 \\
\hline
\end{tabular}


Table.2 Yield and yield parameters of sugarcane as influenced by different establishment techniques and planting geometries

\begin{tabular}{|c|c|c|c|c|}
\hline Treatments & $\begin{array}{c}\text { Number of } \\
\text { millable canes } \\
\text { m }^{-1}\end{array}$ & $\begin{array}{l}\text { Weight per } \\
\text { cane(kg cane } \\
\left.\mathbf{1}^{-}\right)\end{array}$ & $\begin{array}{c}\text { Cane } \\
\text { length }(\mathrm{cm})\end{array}$ & $\begin{array}{l}\text { Cane yield } \\
\left(\mathrm{t} \mathrm{ha}^{-1}\right)\end{array}$ \\
\hline $\begin{array}{l}\mathrm{T}_{1} \text { : Single eye budded setts with wide } \\
\text { row planting }(120 \mathrm{~cm} \text { furrow })\end{array}$ & 9.7 & 1.2 & 221.9 & 113.3 \\
\hline $\begin{array}{l}\mathrm{T}_{2}: \text { Single eye budded setts with paired } \\
\text { row planting }(60 \mathrm{~cm}-120 \mathrm{~cm}-60 \mathrm{~cm})\end{array}$ & 9.8 & 1.2 & 234.1 & 116.3 \\
\hline $\begin{array}{l}T_{3}: \text { Single eye budded setts with dual } \\
\text { row planting }(30 \mathrm{~cm}-150 \mathrm{~cm}-30 \mathrm{~cm})\end{array}$ & 9.9 & 1.3 & 235.0 & 116.9 \\
\hline $\begin{array}{l}\mathrm{T}_{4} \text { : Two eye budded setts with wide row } \\
\text { planting }(120 \mathrm{~cm})\end{array}$ & 10.5 & 1.4 & 241.7 & 123.2 \\
\hline $\begin{array}{l}T_{5}: \text { Two eye budded setts with paired } \\
\text { row planting }(60 \mathrm{~cm}-120 \mathrm{~cm}-60 \mathrm{~cm})\end{array}$ & 10.7 & 1.4 & 245.9 & 125.0 \\
\hline $\begin{array}{l}\mathrm{T}_{6}: \text { Two eye budded setts with dual row } \\
\text { planting }(30 \mathrm{~cm}-150 \mathrm{~cm}-30 \mathrm{~cm})\end{array}$ & 11.5 & 1.4 & 258.4 & 133.0 \\
\hline $\begin{array}{c}\mathrm{T}_{7}: \text { Bud chip seedling with wide row } \\
\text { planting }(120 \mathrm{~cm} \text { furrow })\end{array}$ & 9.0 & 1.2 & 210.8 & 107.5 \\
\hline $\begin{array}{l}\mathrm{T}_{8}: \text { Bud chip seedling with paired row } \\
\text { planting }(60 \mathrm{~cm}-120 \mathrm{~cm}-60 \mathrm{~cm})\end{array}$ & 9.0 & 1.2 & 211.9 & 111.0 \\
\hline $\begin{array}{l}\mathrm{T}_{9} \text { : Bud chip seedling with dual row } \\
\text { planting }(30 \mathrm{~cm}-150 \mathrm{~cm}-30 \mathrm{~cm})\end{array}$ & 9.1 & 1.2 & 214.7 & 113.1 \\
\hline $\begin{array}{l}\mathrm{T}_{10} \text { : Three eye budded setts with } \\
\text { conventional planting }(90 \mathrm{~cm})\end{array}$ & 7.6 & 1.2 & 210.0 & 102.7 \\
\hline S.Em. \pm & 0.4 & 0.03 & 7.6 & 5.2 \\
\hline C.D. $(P=0.05)$ & 1.1 & 0.1 & 22.4 & 15.4 \\
\hline
\end{tabular}

\section{Number of millable canes}

The number of millable canes per meter was significantly differed (Table 2). Results reported that growing of sugarcane with two eye budded setts with dual row planting (30 $\mathrm{cm}-150 \mathrm{~cm}-30 \mathrm{~cm}$ ) recorded significantly maximum number of millable canes per meter (11.5) and it was on par with the two eye budded setts with paired row $(60 \mathrm{~cm}-120 \mathrm{~cm}-$ $60 \mathrm{~cm}$ ) planting (10.7) and two eye budded setts with wide row $(120 \mathrm{~cm})$ planting (10.5). Further, number of millable canes per meter was on par with planting of sugarcane with single eye budded setts and bud chip seedling with different planting geometries. Whereas, conventional planting recorded significantly least number of millable canes (7.6). It might be due to better light penetration into the crop canopy and cross-air circulation because of wider spacing.

Taller cane (Table 1) at wider row spacing is also ascribed to higher light interception, better utilization of nutrients and water that might be resulted in increased crop growth rate which finally produced longer canes. Chattha, et al., (2007) Ghaffar et al., (2012) also reported increased cane height in wider rows compared with narrow row spacing. Positive response of sugarcane crop in terms of yield attributes to various plant geometries 
are reported by Mahadevaswamy and Martin (2002), Soomro et al., (2009) and Ghaffaret al., (2012). This was largely attributed to more number of sugarcane setts per metre, row length leading to produce more tillers, more efficient utilization of moisture, nutrients and solar energy with less inter plant and intra plant competition. These findings are in close conformity with those of Hussain et al., (2005), Chattha et al., (2007), Zafar et al., (2010) and Sarala et al., (2014).

\section{Cane length}

Growing of sugarcane with two eye budded setts with dual row planting $(30 \mathrm{~cm}-150 \mathrm{~cm}$ $30 \mathrm{~cm}$ ) recorded significantly higher cane length $(258.4 \mathrm{~cm})$ and it was on par with the two eye budded setts with paired row $(60 \mathrm{~cm}-$ $120 \mathrm{~cm}-60 \mathrm{~cm})$ planting $(245.9 \mathrm{~cm})$ and two eye budded setts with wide row $(120 \mathrm{~cm})$ planting $(241.7 \mathrm{~cm})$. However, the cane length was on par with planting of sugarcane with single eye budded setts and bud chip seedling with different planting geometries. Whereas, significantly lower cane length $(210 \mathrm{~cm})$ was recorded in planting of sugarcane with three budded setts (Table 2).

This may be due to higher production of photosynthates because of higher vigour, more number of leaves and leaf area per clump and it was the result of amount of dry matter accumulated in stalk.

Because of better establishment at early stages in this treatment compared to three eye budded setts with conventional planting $\left(\mathrm{T}_{10}\right)$ which are slow in establishment.

\section{Single cane weight}

Significantly higher cane weight $(1.4 \mathrm{~kg})$ was recorded with two eye budded setts with dual row planting $(30 \mathrm{~cm}-150 \mathrm{~cm}-30 \mathrm{~cm})$ and it was on par with the two eye budded setts with paired row $(60 \mathrm{~cm}-120 \mathrm{~cm}-60 \mathrm{~cm})$ planting $(1.4 \mathrm{~kg})$ and two eye budded setts with wide row $(120 \mathrm{~cm})$ planting $(1.4 \mathrm{~kg})$. However, the single cane weight was on par with planting of sugarcane with single eye budded setts and bud chip seedling with different planting geometries. Whereas, planting of sugarcane with three budded setts (conventional planting) recorded significantly lower cane weight at harvest $(1.2 \mathrm{~kg})$.

\section{Millable cane yield}

The millable cane yield (133 $\left.\mathrm{t} \mathrm{ha}^{-1}\right)$ was significantly higher in growing of sugarcane with two eye budded setts with dual row planting $(30 \mathrm{~cm}-150 \mathrm{~cm}-30 \mathrm{~cm})$ and it was on par with the two eye budded setts with paired row $(60 \mathrm{~cm}-120 \mathrm{~cm}-60 \mathrm{~cm})$ planting $(125.0 \mathrm{t}$ $\left.\mathrm{ha}^{-1}\right)$ and two eye budded setts with wide row $(120 \mathrm{~cm})$ planting $\left(123.2 \mathrm{t} \mathrm{ha}^{-1}\right)$. However, the cane yield was on par with planting of sugarcane with single eye budded setts and bud chip seedling with different planting geometries.

Whereas, significantly least millable cane yield (102.7 $\left.\mathrm{t} \mathrm{ha} \mathrm{ha}^{-1}\right)$, was recorded in conventional planting (Table 2). The increased cane and sugar yield might be due to better light interception, greater availability of moisture, more aeration to individual setts and increased plant population which led to better tillering tiller retention, taller canes and increased cane weight at harvest over the rest of plant geometries.

Favourable effect of wider row planting on cane and sugar yield in sugarcane has also been reported by Sundara (2003). Similarly, significantly more number of millable canes and higher single cane weight had contributed to increase in cane and sugar yields.

These findings are in conformity with the findings of Jayeshsingh et al., (2013), 
Chitkaladevi et al., (2011) and Ullahet al., (2016). Thus, overall better growth performance and higher values of most of the yield attributes at dual row planting than conventional method of planting resulted in significantly higher cane and sugar yields with two eye budded setts with dual row planting $\left(\mathrm{T}_{6}\right)$.

Results of this study indicated that, growing of sugarcane with two eye budded setts with dual row planting was better to get higher millable cane yield. Further, this technique may help to reduce the cost of production and also suitable for mechanical harvesting.

\section{References}

Ahmed Iftikhar, 2002, Bio-economic efficiency of spring planted sugarcane as influenced by spatial arrangement and nutrient management. M.Sc. Thesis submitted to Department of Agronomy, Univ. of Agric., Faisalabad, Pakistan.

Bathla, A. V. L. and Sharma, H. L., 1978, Measurement of leaf area of sugarcane. Indian Sugar Crops J., 5 (1): 16-17.

Chattha, M.U., Ali, A. and Bilal, M., 2007, Influenced of planting techniques on growth and yield of spring planted sugarcane (Saccharum officinarum L.). Pakistan J. Agric. Sci., 44 (3): 452456.

Cheema, I. A. M., Ayub, M. and Jabbar, A., 2002, Morphological response of spring planted sugarcane to spaced arrangement and nutrient management. Pakistan Sugar J., 17 (6): 62-68.

Chitkaladevi, T., Bharathalakshmi, M., Gouri, V., Kumari M. B. G. S., Naidu, N. V. and Prasadarao, K., 2011, Studies on the effect of sett size, seed rate and sett treatment on yield and quality of sugarcane. Indian J. sugarcane tech., 26(2): 4-6.
Ghaffar, A., Ehsanullah., Akbar, N., Khan, S. H., Jabran, K., Hashmi, R. Q., Iqbal, A. and Ali, M. A., 2012, Effect of trench spacing and micronutrients on growth and yield of sugarcane (Saccharum officnarum L.). Australian J. Crop Sci., 6(1):1-9.

Gomez, K. A. and Gomez, A. A., 1984, Statistical Procedures for Agricultural Research, $2^{\text {nd }}$ Edn. John Wiley and Sons. New York, p. 639.

Hussain, M. S., Singh, V. P. and Sudhirkumar, S., 2005, Effect of variety and wider row spacing on plant population, cane yield and juice quality. Bhartiya Sugar, 29(3): 34-37.

Jayesh Singh, Rajender, K. and Uppal, S. K., 2013, Effect of sett size, seed rate and sett treatment on growth and productivity of sugarcane (Saccharum officinarum L.). J. Res. Punjab Agric. Univ., 50 (1\&2): 5-7.

Mahadevaswamy, M. G. T. and Martin, 2002, Production potential for wide row sugarcane inter-cropped with aggregatum onion. Indian J. Agron., 47 (3): 361-366.

Rehman, A-UR., Ehsanullah, Ahmad, R. and Jabbar, A., 2013, Interactive study of row spacing $\mathrm{s}$ and foliar application of macro and micro nutrients on growth, yield and quality of sugarcane (Saccharum officinarum L.). Pakisthan J. Bot., 45 (2): 427-433.

Sarala, N. V., Subba Rao, M., Hemanth, K. M. and Nagamadhuri, K. V., 2014, Response of sugarcane to plant geometry and irrigationmethods in southern agro - climatic zone of Andhra Pradesh. J. Sugarcane Res., 4 (1): 86-90.

Sestak, Z., Catsky, J. and Sarris, P. G., 1971, Plant synthesis in Production Manual of Methods. W. Junk, N. V. N. V. Publication. The Hague, pp. 343-381.

Shinde, S. H., Dahiwalkar, S. D. and Berad, S. 
M., 2000, Response of sugarcane to planting technique and fertigation through drip. Bharatiya Sugar, 25(3): 19-24.

Singh, A. K., Lal, M. and Prasad, S. R., 2006, Effect of row spacing and nitrogen on ratoonability of early maturing high sugar genotypes of sugarcane (Saccharum spp. hybrid). Indian $J$. Agril. Sci., 76(2): 108-10.

Soomro, A. F., Arain, M. Y., Panhwar, R. N., Rajput, M. A. and Gujar, N., 2009, Effect of spacing and seed placement on yield and yield contributing characters of sugarcane variety thatta10 under agro ecological conditions of Thatta. Pakistan J. Sci., 61 (2): 110115.

Sundara, B., 2000, Sugarcane cultivation.
VIKAS Publishing House Pvt. Ltd. New Delhi. India.

Sundara, B., 2003, Sugarcane varietal response to wide row spacing. Indian Sugar, LII (8): 573-578.

Ullah, S., Anjum, S. A., Raza, M. M., Riaz, A., Abbas, A., Yousif, M. M., Ma, J. C., Liu, Y.X., Zhang, J. J., Cheng, D.W., Xu, Y.X. and Ali, I., 2016, Optimizing row spacing to ameliorate the productivity of spring sugarcane (Saccharum officinarum L.). Agricl. Sci., 7:531-538.

Zafar, M., Tanveer, A., Cheema, Z. A. and Ashraf, M., 2010, Weed-crop competition effects on growth and yield of sugarcane planted using two methods. Pakistan J. Bot., 42 (2):815823.

\section{How to cite this article:}

Maruthi, D. Krishnamurthy, Y.M. Ramesh, B.M. Chittapur and Ashokkumar Gaddi. 2019. Performance of Sugarcane under Different Establishment Techniques and Planting Geometries. Int.J.Curr.Microbiol.App.Sci. 8(11): 293-301. doi: https://doi.org/10.20546/ijcmas.2019.811.037 